\title{
PENELITIAN HUBUNGAN PARAMETER SENSORI (DEMERIT POINT SCORE), KIMIA, DAN MIKROBIOLOGI PADA KEMUNDURAN MUTU IKAN NILA SELAMA PENGESAN
}

\author{
Farida Ariyani*), Jovita Tri Murtini*), dan Fairdiana Andayani*)
}

\begin{abstract}
ABSTRAK
Penelitian hubungan parameter sensori dengan parameter kimiawi dan mikrobiologi pada penurunan kesegaran ikan nila selama pengesan telah dilakukan. Ikan nila hidup dimatikan secara hypothermia, kemudian disusun dalam kotak berinsulasi yang berisi es dengan perbandingan es : ikan $=2: 1(\mathrm{~b} / \mathrm{b})$. Ikan dalam kotak yang berisi es tersebut disimpan pada suhu ruang dan setiap hari dilakukan penggantian es yang mencair. Pengamatan terhadap penurunan kesegaran ikan dilakukan setiap 3 hari secara sensori (Demerit Point Scores/DPS), kimiawi (Total Volatile Base/TVB, $K$ value), dan mikrobiologi (Angka Lempeng Total/ALT) sampai ikan dinyatakan ditolak oleh panelis. Hasil penelitian menunjukkan bahwa sampai dengan penyimpanan 15 hari dalam es, ikan nila segar masih diterima panelis, namun setelah 18 hari penyimpanan, sudah tidak layak untuk dikonsumsi. Pada penyimpanan 18 hari DPS mencapai 25,9 , nilai TVB mencapai $48 \mathrm{mgN} \%, K$ value mencapai $76,4 \%$, dan nilai ALT 5,0 x $10^{5} \mathrm{cfu}$. Hasil pengamatan terhadap korelasi parameter uji menunjukkan bahwa DPS berkorelasi positif dengan nilai TVB maupun $K$ value tetapi tidak berkorelasi positif dengan nilai jumlah bakteri total.
\end{abstract}

\begin{abstract}
Research on the correlation of sensory (Demerit Point Score), chemical and microbiological parameters during deterioration process of fresh tilapia stored in ice. By: Farida Ariyani, Jovita Tri Murtini, and Fairdiana Andayani
\end{abstract}

\begin{abstract}
Research on the correlation of sensory (Demerit Point Score), chemical, and microbiological parameters during deterioration process of fresh tilapia stored in ice has been conducted. Live tilapia was killed by hypothermia method (immersing in ice water) and subsequently arranged in insulated box filled with flake ice with the ratio of ice and fish of 2:1 (w/w). The ice in boxes was checked and melted ice was replaced every day. The box was stored at ambient temperature and observation on freshness changes of tilapia was done every 3 days for sensory (Demerit Point Scores/DPS), chemical (TVB, $K$ value) and microbiological (TPC) qualities until the fish was rejected by panelists. Results of the experiment showed that after 15 days storage, fresh tilapia was still accepted by panelists, however, after being stored for 18 days, tilapia was unfit for human consumption with the value of DPS 25.9, TVB $48 \mathrm{mgN} \%, \mathrm{~K}$ value $76.4 \%$ and TPC $5.0 \times 10^{5} \mathrm{cfu}$. It was shown that DPS correlated well with TVB as well as $K$ value but did not correlate well with total bacteria.
\end{abstract}

\section{KEYWORDS: deterioration, fresh tilapia, demerit point score, TVB, $K$ value, TPC correlation}

\section{PENDAHULUAN}

Penanganan produk perikanan yang salah/kurang tepat merupakan salah satu penyebab rendahnya kualitas kebanyakan produk perikanan segar dan olahan. Sebagai bahan pangan, kualitas produk perikanan segar ataupun olahan sering di bawah persyaratan yang ditetapkan karena penanganan yang kurang tepat pada ikan tersebut semenjak ikan ditangkap, selama transportasi/distribusi dan atau saat sampai ke tangan konsumen.

Dalam menentukan kualitas produk perikanan segar maupun olahan, diperlukan cara yang mudah, cepat dan akurat. Penilaian secara sensoris pada produk perikanan segar selama ini merupakan cara yang mudah dan cepat. Meskipun demikian kelemahan dari cara ini adalah tingginya tingkat subyektivitas dari para panelis, terlebih apabila panelis yang melakukan penilaian bukan panelis terlatih. $\mathrm{Di}$ sisi lain, kualitas ikan yang ditentukan secara sensoris belum mencerminkan kualitas ikan secara obyektif yang didasarkan pada parameter uji secara kuantitatif baik untuk perubahan kimiawi maupun mikrobiologi, sementara standar yang banyak digunakan oleh Badan Standardisasi maupun Industri adalah parameter kimia maupun mikrobiologi. Dengan demikian diperlukan kajian yang mengaitkan antara parameter sensori dengan parameter kimiawi dan mikrobiologi. Beberapa metode uji sensori telah dikembangkan, termasuk metode Indek Kualitas yang

" Peneliti pada Balai Besar Riset Pengolahan Produk dan Bioteknologi Kelautan dan Perikanan, Balitbang KP, KKP;

JI. KS. Tubun Petamburan VI, Slipi, Jakarta Pusat; E-mail: idapoernomo@yahoo.co.id 
didasarkan pada Demerit Point Scores/DPS dengan pengertian bahwa semakin rendah nilai hasil penilaian panelis semakin tinggi kualitas ikan (Huss, 1995). Penilaian dengan DPS relatif lebih mudah, cepat, dan didasarkan pada penilaian deskriptif yang dikuantifikasikan untuk menentukan kualitas kesegaran ikan (Branch \& Vail, 1985; Bremner et al.,1985). Atribut yang dinilai meliputi kenampakan umum, mata, insang, perut, anus, dan rongga perut. Nilai untuk setiap atribut diset pada kisaran 0-3 yang proporsional dengan pola deteriorasi untuk setiap jenis ikan. Nilai 0 untuk ikan dengan kesegaran prima dan nilai 3 untuk atribut ikan yang telah mengalami deteriorasi lanjut. Metode ini telah diterapkan untuk mengevaluasi penurunan kesegaran ikan whiting (Luten et al., 1997), ikan sea bream (Alasalvar et al., 2002), filet nila (Soccol et al., 2005), dan ikan nila utuh selama pengesan (Ariyani \& Dwiyitno, 2010). Adapun metode kimiawi dan mikrobiologi yang telah dikembangkan dan banyak digunakan untuk mengidentifikasi penurunan mutu pada ikan segar antara lain $K$ value (Uchiyama et al., 1972), TMA, TVB (Huss, 1995), histamin (Hardy \& Smith, 1976), TPC (BSN, 2006), dan bakteri pembentuk histamin (Niven et al., 1981).

Pengamatan terhadap kemunduran mutu filet nila selama penyimpanan telah dilakukan beberapa peneliti sebelumnya. Liu et al. (2010) mengamati perubahan kesegaran filet nila dalam pengemas yang dies secara sensori dengan metode Ruiz-Capillas and Moral yang dimodifikasi, sedangkan Soccol et al. (2005) melihat perubahan filet nila dengan Modified Atmospher Packaging (MAP) dalam suhu chilling secara sensori menggunakan metode Dutcosky dan secara hedonik dengan skala 1-9. Pada percobaan pengamatan kemunduran mutu ikan nila segar dalam es yang dilakukan secara sensori dengan metode DPS menunjukkan bahwa penurunan kesegaran ikan nila dalam es mempunyai korelasi positif dengan peningkatan waktu penyimpanan dengan nilai korelasi $r=0,97$ (Ariyani \& Dwiyitno, 2010). Dengan mempertimbangkan bahwa metode DPS relatif lebih mudah dan sederhana, maka perlu kajian hubungan parameter sensoris dengan kimiawi dan mikrobiologi pada kemunduran mutu ikan nila selama pengesan, dengan harapan bahwa apabila nilai DPS telah diketahui dapat digunakan untuk memperkirakan nilai mutu secara kimiawi maupun mikrobiologi.

\section{BAHAN DAN METODE}

Pada kegiatan ini dilakukan pengamatan pola hubungan antara hasil penilaian secara sensori dengan kualitas kimiawi dan mikrobiologi ikan nila sebagai ikan hasil budidaya selama penyimpanan dalam es.
Ikan nila hidup yang digunakan sebagai bahan baku percobaan diperoleh dari pembudidaya di Cisaat Sukabumi Jawa Barat. Teknik transportasi basah (ikan dimasukkan ke dalam kantong plastik yang berisi $1 /$ 4 bagian air dan $3 / 4$ bagian oksigen dan dimasukkan ke dalam kotak styrofoam) digunakan untuk membawa ikan nila hidup dari pembudidaya ke Laboratorium Balai Besar Riset Pengolahan Produk dan Bioteknologi Kelautan dan Perikanan (BBRP2BKP), Jakarta. Selanjutnya ikan dimatikan dengan cara pengesan (hypothermia : suhu air es 0$6^{\circ} \mathrm{C}$ ) selama 30-45 menit, dan disimpan pada suhu dingin (dalam cool box berisi es dengan perbandingan ikan : es 1:2 b/b). Pengamatan dilakukan setiap 3 hari sampai ikan ditolak secara sensori. Parameter yang diamati meliputi sensori (Demerit Point Scores/ DPS) menurut metode Branch \& Vail (1985), kimiawi ( $k a d a r$ air, TVB, $K$ value) menurut metode Miwa \& Ji (1992), dan mikrobiologi (ALT) menurut metode SNI 01-332.2006 (BSN, 2006). Pada pengamatan sensoris secara DPS, setiap atribut diberi nilai 0 sampai 3 dengan kriteria nilai 0 menunjukkan kualitas prima/ sangat segar dan nilai 3 menunjukkan kualitas paling rendah. Nilai dari masing-masing atribut dijumlahkan sehingga kisaran nilai total penerimaan adalah 0-39 (Branch \& Vail, 1985). Penilaian secara sensori dilakukan oleh 6 orang panelis terlatih. Percobaan dirancang menggunakan rancangan acak lengkap dengan 1 faktor perlakuan yaitu lama penyimpanan dengan 7 kali ulangan.

\section{HASIL DAN BAHASAN}

Ikan nila yang digunakan sebagai bahan baku mempunyai karakteristik bobot 201,11 $\pm 29,45$ gram,

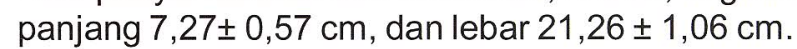

\section{Perubahan Secara Sensoris}

Penilaian organoleptis dilakukan terhadap atribut kenampakan umum, mata, insang, perut, anus, dan rongga perut dengan skala $0-39$. Hasil penilaian 6 panelis terlatih terhadap atribut mutu nila segar selama pengesan dengan metode DPS dapat dilihat pada Gambar 1.

Berdasarkan Gambar 1, terlihat bahwa selama penyimpanan, terjadi peningkatan DPS seiring dengan peningkatan waktu penyimpanan yang berarti bahwa semakin tinggi DPS, semakin rendah kualitas ikan. Sampai dengan penyimpanan 15 hari dalam es ikan nila segar masih diterima panelis, namun setelah 18 hari penyimpanan ikan sudah tidak layak untuk dikonsumsi dengan DPS mencapai 25,9. Besarnya DPS pada saat terjadi penolakan oleh panelis bervariasi tergantung pada jenis ikan. Pada ikan blue grenadier (M. novaezelandiae), DPS mencapai 29 


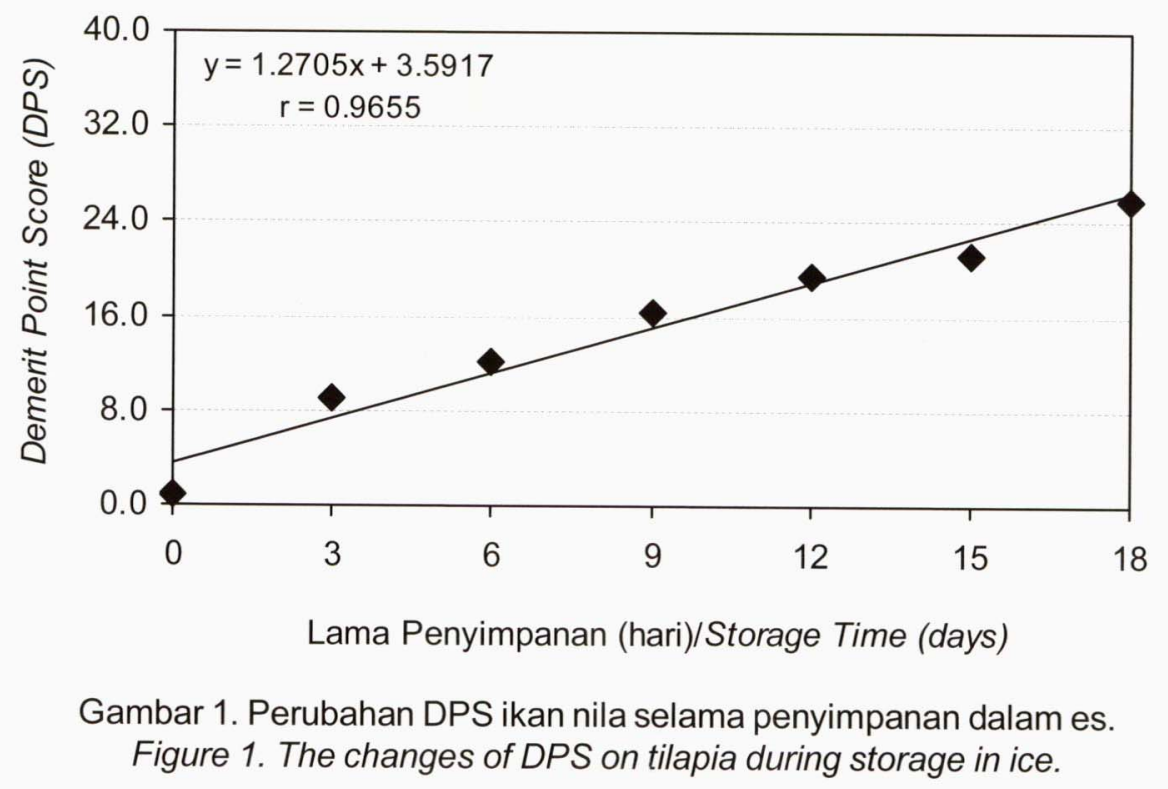

dengan penyimpanan 17 hari, sedangkan pada ikan whiting $(H$. semifasciata), DPS mencapai 31 pada penyimpanan 19 hari (Rahman \& Olley, 1984). Dilihat dari polanya, hubungan antara DPS dengan waktu penyimpanan adalah linier dengan $r=0,97$ (Ariyani \& Dwiyitno, 2010). Hal ini berarti bahwa penurunan DPS dengan peningkatan waktu penyimpanan hampir berjalan seiring. Tingginya nilai korelasi ini hampir sama dengan nilai korelasi antara nilai sensori filet nila menggunakan metode Ruiz-Capillas and Moral dengan lama waktu penyimpanan pada penelitian yang dilakukan Soccol et al. (2005), yakni $r=0,95$, maupun nilai korelasi antara nilai sensori filet nila menggunakan metode Indeks Kualitas dengan lama waktu penyimpanan dengan nilai $r=0,94$ (Odoli, 2009). Hal ini menunjukkan bahwa observasi kemunduran kesegaran ikan selama pengesan menggunakan metode DPS dapat digunakan sebagai dasar dalam penentuan tingkat kesegaran ikan nila utuh secara sensori selama penyimpanan dalam es.

\section{Perubahan Secara Kimiawi}

\section{Total Volatile Base (TVB)}

Selama penyimpanan, angka TVB terlihat semakin meningkat dengan bertambahnya lama penyimpanan dan pola kenaikannya mengikuti pola polinomial tipe kuadratik. Peningkatan pada awal penyimpanan sampai dengan hari ke 9 terlihat sedikit lambat, kemudian meningkat lebih tajam pada penyimpanan selanjutnya (Gambar 2). Pola ini mirip dengan hasil

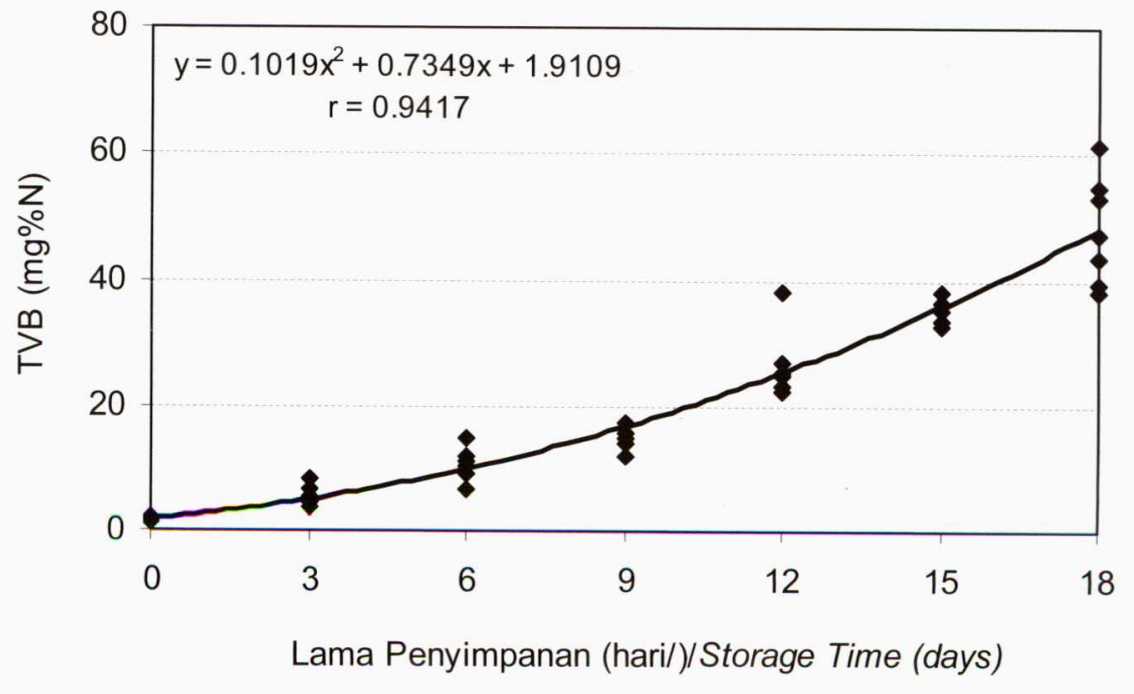

Gambar 2. Perubahan angka TVB ikan nila selama penyimpanan dalam es.

Figure 2. The changes of TVB value on tilapia during storage in ice. 
penelitian Okeyo et al. (2009) yang menunjukkan bahwa kenaikan TVBN nile perch (Lates niloticus) yang disimpan dalam es berjalan lambat sampai dengan 10 hari penyimpanan kemudian meningkat tajam pada penyimpanan berikutnya, sedangkan pada penelitian Ozogul \& Ozogul (2000) peningkatan nilai TVB pada ikan rainbow trout selama penyimpanan pada suhu dingin baru terlihat signifikan setelah 7-9 hari penyimpanan. Kondisi ini menunjukkan bahwa TVB baru terbentuk setelah proses degradasi protein berlanjut, dan bukan pada saat terjadi deteriorasi awal komponen ikan. Pada pengamatan hari ke 18 pada penelitian ini, nilai TVB berkisar 48,19 $\pm 7,94 \mathrm{mgN} \%$ dan telah melebihi $30 \mathrm{mgN} \%$ yang merupakan batas penerimaan TVB ikan segar pada umumnya (Sikorski et al., 1990). Meskipun demikian nilai batas maksimal TVB untuk ikan segar ini sering bervariasi tergantung pada spesies dan cara penyimpanannya. Pada penelitian Okeyo et al. (2009), pada hari ke 18 nilai TVB mencapai $21,9 \mathrm{mgN} \%$ dan baru ditolak panelis pada hari ke 22 dengan nilai TVB $26,0 \mathrm{mgN} \%$, sedangkan hasil penelitian Adoga et al. (2010), menginformasikan bahwa ikan nila yang disimpan dalam es ditolak panelis pada hari ke 21 dengan nilai TVB 38,75 mgN\%. Sedikit berbeda dengan filet nila yang dikemas dalam kantung plastik tanpa pengaturan gas di dalamnya maupun dengan Modified Atmospheric Packaging (MAP) dan disimpan dalam es (suhu penyimpanan $\pm 1^{\circ} \mathrm{C}$ ), pola kenaikan angka TVB tidak terlihat nyata selama penyimpanan dan baru meningkat secara nyata pada akhir penyimpanan (Soccol et al., 2005; Martinsdottir et al., 2009). Perbedaan ini disebabkan pada filet nila yang disimpan dalam kantung plastik, jumlah total bakteri di dalam kantung relatif lebih sedikit karena rekontaminasi dapat diminimalisasi sehingga kemampuan bakteri untuk mengubah senyawa non protein nitrogen menjadi rendah. Adapun pengemasan dengan cara MAP mampu mengurangi jumlah oksigen yang sangat diperlukan bakteri untuk menunjang aktivitasnya termasuk dalam mengubah senyawa non protein nitrogen menjadi basa menguap (TVB).

\section{Kvalue}

$K$ value merupakan salah satu indikator untuk mengetahui tingkat kesegaran ikan karena $K$ value menghitung hasil degradasi komponen nukleotida (Adenosine Triphosphate/ATP) yang terjadi pada proses kemunduran mutu ikan (Uchiyama et al., 1972). Peningkatan $K$ value pada penelitian ini terlihat nyata selama penyimpanan. Hal ini mendukung hasil penelitian Liu et al. (2010) yang menunjukkan bahwa terdapat korelasi positif antara $K$ value dan lama waktu penyimpanan $(r=0,97)$ filet nila yang dikemas secara MAP dan disimpan dalam es. Sedikit berbeda dengan peningkatan TVB, peningkatan $K$ value berjalan lebih cepat pada awal penyimpanan dan mulai berjalan lambat setelah 9 hari penyimpanan (Gambar 3). Pola peningkatan $K$ value ini menunjukkan bahwa proses degradasi ATP menjadi komponen yang lebih sederhana (Inosine Monophosphate/IMP, inosin, hypoxanthine) merupakan proses biokimiawi awal yang terjadi segera setelah ikan mati, sementara proses pembusukan belum dimulai (Rodriques-Jeres et al., 2011). Sebaliknya, TVB merupakan parameter indikator yang merefleksikan terjadinya proses pembusukan ikan yang terjadi pada pertengahan hingga akhir proses pembusukan karena degradasi komponen protein oleh aktivitas mikroba menjadi basa menguap. Segera setelah ikan mati, nilai $K$ value masih sangat rendah yakni berkisar $4,03 \pm 0,58 \%$.

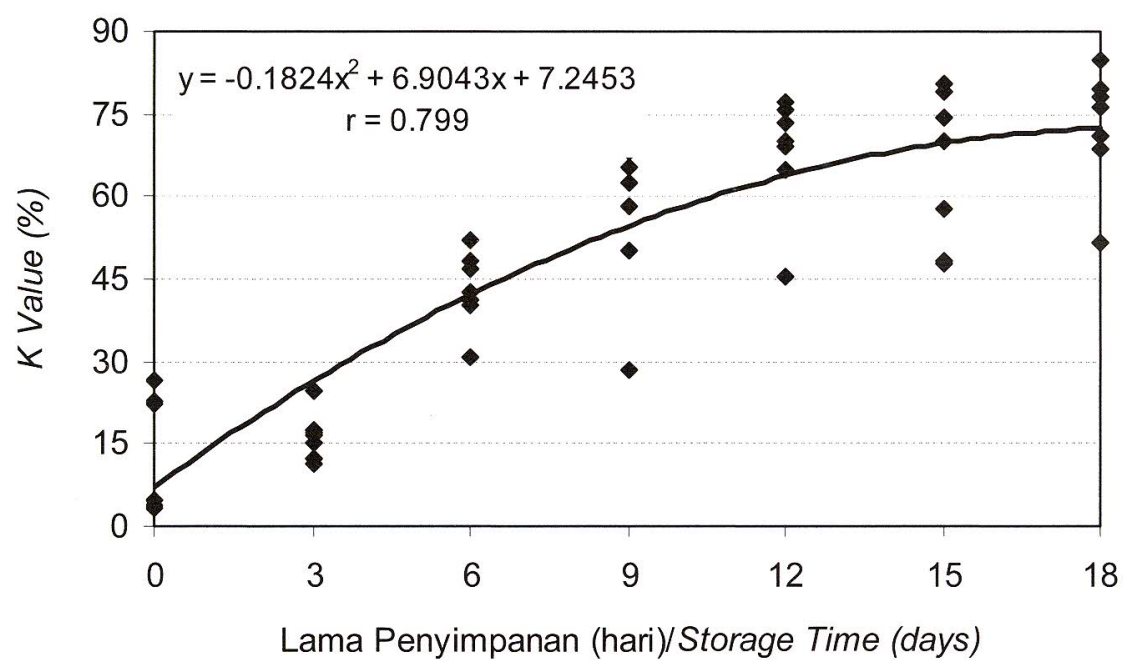

Gambar 3. Perubahan $K$ value ikan nila selama penyimpanan dalam es. Figure 3. The changes of $K$ value on tilapia during storage in ice. 
Hal ini sesuai dengan pernyataan Uchiyama et al. (1972) bahwa K value pada daging ikan segera setelah ikan mati adalah di bawah 5\%, sedangkan setelah 3 hari penyimpanan $K$ value mencapai kisaran $14,95 \pm$ $2,64 \%$, yang setara dengan kondisi ikan pada saat didaratkan di TPI dan dapat digunakan sebagai bahan baku sushi atau sashimi. Daging ikan yang diperuntukkan sebagai bahan baku kamaboko dan surimi mempunyai kisaran $K$ value 40-60\% (Uchiyama et al., 1972) dan pada penelitian ini daging pada kondisi tersebut diperoleh pada daging nila setelah penyimpanan 6 hari ( $K$ value : $43,88 \pm 3,07 \%$ ).

Pola hubungan $K$ value dengan waktu penyimpanan pada ikan nila yang disimpan dalam es mengikuti pola polynomial tipe kuadratik dengan nilai $r=0,80$. Kenaikan $K$ value sampai dengan penyimpanan 9 hari terlihat cepat kemudian melambat pada sisa waktu penyimpanan. Pada grafik yang berpola polinomial, setelah kenaikan maksimal kemudian relatif konstan akan terjadi penurunan pada titik tertentu. Meskipun pada penelitian ini belum terlihat terjadinya penurunan sampai akhir penyimpanan, kemungkinan ini dapat terjadi pada pola kenaikan $K$ value selama penyimpanan ikan segar dalam es sebagaimana hasil penelitian Wijayanti et al. (2006) yang menunjukkan bahwa $K$ value pada ikan cakalang yang disimpan dalam es meningkat sampai dengan 9 hari penyimpanan, kemudian menurun pada penyimpanan selanjutnya. Penurunan $K$ value ini kemungkinan disebabkan terjadinya penguraian lebih lanjut dari hypoxanthine menjadi xanthine dan uric acid terutama pada tahap akhir dari penyimpanan (Ozogul et al., 2000; Alasalvar et al., 2002).

Pola kenaikan $K$ value pada ikan selama penyimpanan dalam es bervariasi tergantung pada jenis ikan dan cara penangkapan atau cara mematikannya. Pada ikan seabream hasil budidaya yang disimpan dalam es, $K$ value terlihat meningkat secara konstan sampai akhir penyimpanan (Alasalvar et al., 2002), sedangkan pada ikan flounder, $K$ value meningkat dengan peningkatan waktu yang signifikan dan mencapai $72 \%$ pada 12 hari penyimpanan (Massa et al., 1998). Berbeda dengan ikan common sole yang disimpan dalam es, $K$ value awal sebelum penyimpanan telah tinggi yakni $32,92 \%$ kemudian meningkat secara linier dengan bertambahnya waktu penyimpanan dan mencapai $97,88 \%$ pada 24 hari penyimpanan (Ozogul et al., 2011). Urbieta \& Ginés (2011) menyatakan bahwa cara mematikan ikan juga berpengaruh pada perbedaan kenaikan $K$ value selama penyimpanan. Ikan gilthead yang dimatikan dalam kepingan es dan disimpan selama 15 hari, mempunyai $K$ value yang lebih tinggi secara nyata $(22,4 \%)$ dibanding dengan ikan yang dimatikan dalam air es $(7,65 \%)$ pada penyimpanan yang sama. Hal serupa juga dinyatakan oleh Ahimbisibwe et al. (2010) bahwa ikan amberjack (Seriola dumerili) dan red seabream (Pagrus major) yang dimatikan dengan cara bleeding (pemotongan pembuluh darah di bagian kepala) mempunyai $K$ value yang lebih kecil dari $K$ value ikan seabream (Pagrus major) yang dimatikan dengan cara unbleeding (pemukulan di bagian kepala).

\section{Perubahan secara Mikrobiologi}

Perubahan log ALT (jumlah total bakteri) selama penyimpanan tidak terlihat nyata dan cenderung konstan dengan bertambahnya waktu penyimpanan (Gambar 4). Hal ini kemungkinan disebabkan terhambatnya pertumbuhan bakteri karena suhu dingin, di samping itu juga terjadi leaching/pencucian oleh air hasil pencairan es selama penyimpanan, mengingat bahwa ikan nila pada penelitian ini disimpan

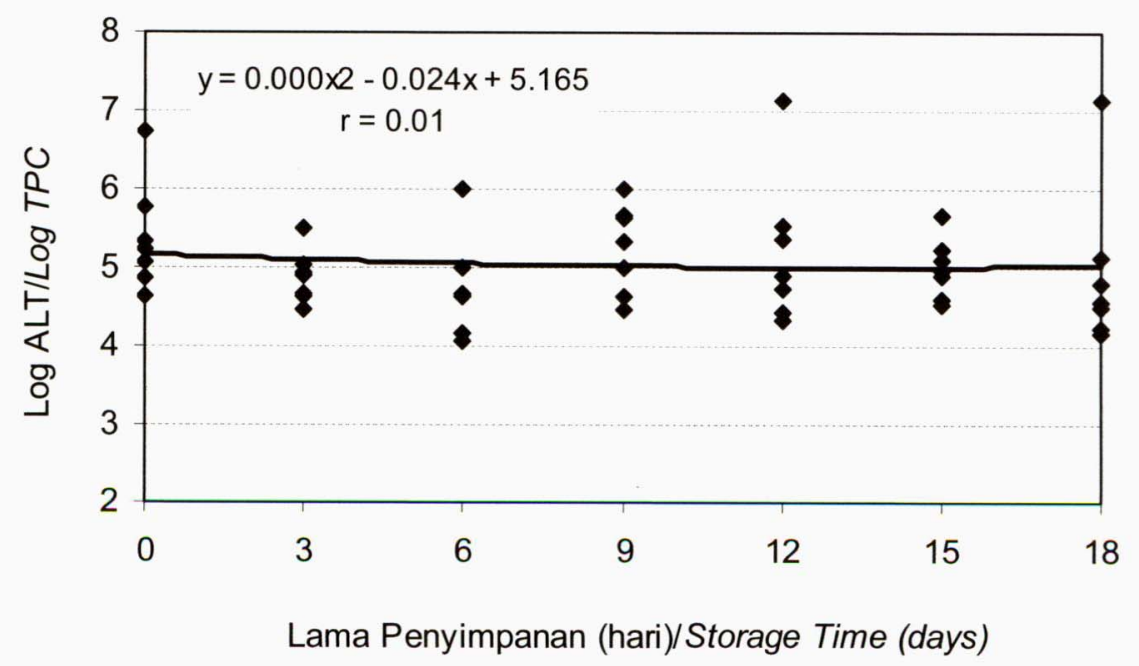

Gambar 4. Perubahan log jumlah bakteri total ikan nila selama penyimpanan dalam es.

Figure 4. The changes of log total bacteria of tilapia during storage in ice. 
langsung dalam es curah tanpa pengemasan terlebih dahulu. Kenyataan ini mendukung Bremner et al. (1988) yang menyatakan bahwa pada penyimpanan ikan dalam es pada suhu tropis, bakteri mesophilic dan thermophilic menjadi terhambat pertumbuhannya karena penambahan es, dan juga terjadi pencucian/ leaching yang signifikan ketika air hasil pelelehan es mencuci permukaan ikan. Dikatakan lebih lanjut bahwa umur simpan ikan dalam es di daerah tropis lebih banyak berkaitan dengan penguraian AMP dari pada aktivitas bakteri. Hasil penelitian Lougovoisa et al. (2003), juga menunjukkan bahwa nilai jumlah bakteri total bukan merupakan parameter yang tepat untuk mengukur mutu kesegaran ikan selama penyimpanan dalam es karena korelasi hanya diperoleh sampai 4 hari penyimpanan, sedangkan pada sisa waktu penyimpanan tidak tercermin korelasi positif antara jumlah bakteri total dengan lama waktu penyimpanan. Berbeda dengan pola pertumbuhan bakteri pada filet nila dengan kemasan plastik yang disimpan dalam es, nilai jumlah bakteri total mencapai 8,6 log cycle pada hari ke-16 penyimpanan, tetapi pada penyimpanan selanjutnya (hari ke 20) nilai jumlah bakteri total mengalami penurunan yang diduga disebabkan oleh perubahan komposisi gas (headspace) karena penurunan $\mathrm{O}_{2}$ dan kenaikan $\mathrm{CO}_{2}$ sebagai hasil metabolism bakteri di dalam kantung plastik yang berakibat pada penghambatan pertumbuhan bakteri (Odoli, 2009). Demikian juga dengan filet nila yang dikemas secara Modified Atmosphere (MA) dan disimpan pada suhu dingin, perkembangan jumlah bakteri total sampai akhir penyimpanan tidak terlihat signifikan karena keterbatasan $\mathrm{O}_{2}$ dalam kemasan yang menghambat pertumbuhan mikroba.

\section{Korelasi antara Parameter Sensori dengan Parameter Kimiawi dan Mikrobiologi}

Pada Gambar 5, terlihat bahwa pola hubungan antara TVB dengan DPS pada ikan nila selama pengesan positif dengan pola polinomial tipe kuadratik $(r=0,91)$, sedangkan nilai korelasi/hubungan yang serupa pada ikan nile perch sebesar 0,97 (Okeyo et al., 2009). Semakin tinggi nilai DPS semakin tinggi angka TVB. Meskipun demikian, pada penelitian ini terlihat bahwa laju kenaikan angka TVB di awal penyimpanan agak lambat meskipun laju kenaikan DPS tetap. Sampai dengan 9 hari penyimpanan dalam es, nilai rata-rata TVB sebesar $15,08 \mathrm{mg} \% \mathrm{~N}$ masih di bawah batas maksimal yang ditetapkan untuk ikan segar yaitu 30-35 mg TVB-N/100 g (Huss, 1995) sementara DPS sebesar 16,4 . Nilai TVB $(35,71$ $\mathrm{mg} \% \mathrm{~N}$ ) terlihat mulai melebihi ambang batas untuk ikan segar setelah 15 hari penyimpanan, sedangkan DPS mencapai 21,3 dan sampel masih diterima panelis. Pada saat ikan ditolak panelis (18 hari penyimpanan), nilai TVB sebesar $49,19 \mathrm{mg} \% \mathrm{~N}$ dan telah melampaui standar yang ditetapkan untuk ikan segar pada umumnya, sedangkan DPS mencapai 25,9 atau $66,41 \%$ dari maksimal skor pada lembar DPS (39). Rendahnya persentase total DPS ini salah satunya disebabkan adanya beberapa atribut yang tidak berkorelasi positif dengan waktu penyimpanan seperti atribut kondisi kulit, lendir permukaan, dan kondisi anus (Ariyani \& Dwiyitno, 2010). Korelasi positif juga terjadi antara nilai TVB dan nilai penerimaan sensori pada filet nila yang dikemas dalam kemasan plastik dan disimpan dalam es dengan nilai korelasi 0,93 (Liu et al., 2010). Pernyataan yang sama juga disampaikan oleh Özyurt et al. (2009)

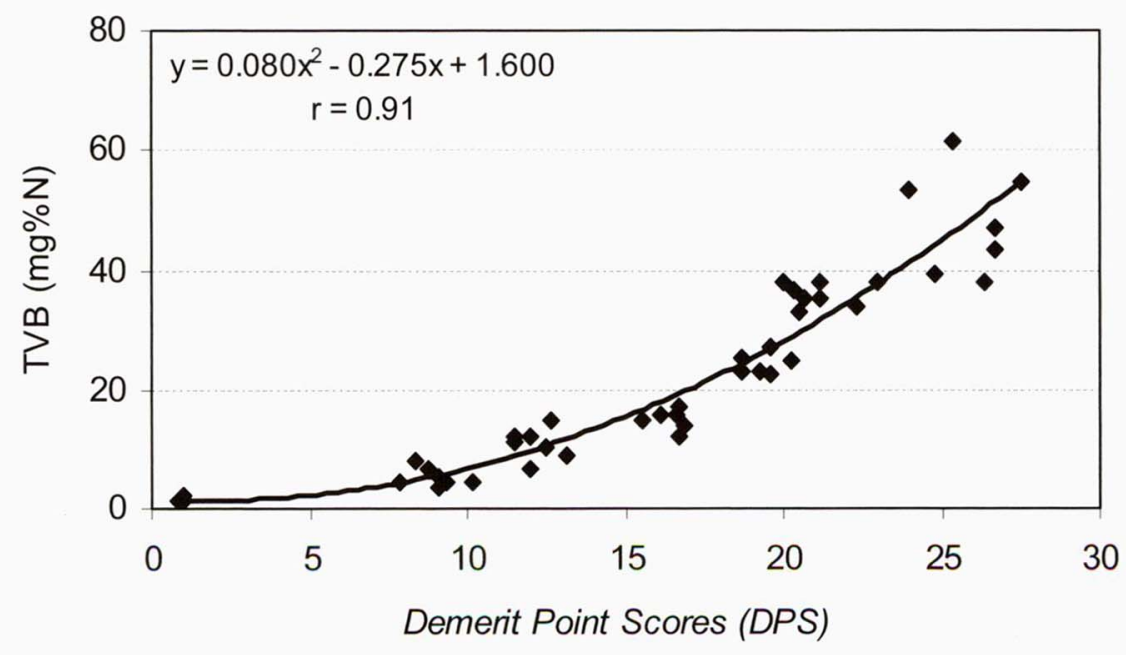

Gambar 5. Pola hubungan antara DPS dengan angka TVB pada ikan nila selama penyimpanan dalam es. Figure 5. Correlation between DPS and TVB of tilapia during storage in ice. 
yang melihat korelasi antara nilai TVB dengan nilai sensori (Quality Index Method) pada ikan red mullet (Mullus barbatus) dan goldband (Upeneus moluccensis) selama penyimpanan dalam es.

TVB merupakan hasil degradasi protein terutama oleh aktivitas bakteri, dan juga oleh aktivitas enzim meskipun sedikit (Huss, 1995). Pada ikan yang tidak mengandung senyawa Tri MethylAmine Oxide (TMAO), deteriorasi lebih banyak disebabkan oleh deaminasi asam amino sehingga pembentukan TVB agak lambat (Huss, 1995). Di samping itu, deteriorasi awal pada umumnya disebabkan oleh aktivitas enzim (autolisis) yang pada saat itu aktivitas bakteri belum tinggi dan proses pembusukan ikan belum terjadi sehingga, berakibat pada rendahnya kadar TVB di awal waktu penyimpanan. Sementara itu Howgate (2010) menyatakan bahwa hilangnya komponen basa menguap pada ikan yang disimpan dalam es kemungkinan terjadi karena leaching sedangkan Oehlenschlager (1997) menyatakan bahwa terdapat kemungkinan terjadinya pencucian senyawa TVB pada minggu pertama penyimpanan ikan dalam es yang berakibat pada lambatnya kenaikan bahkan stabilnya nilai TVB pada awal penyimpanan tersebut.

Pola hubungan $K$ value dengan DPS pada penelitian ini cenderung linier dengan nilai $r=0,75$ (Gambar 6) yang berarti laju kecepatan perubahan keduanya relatif sama. Hasil ini mendukung hasil penelitian Luten et al. (1997) yang menunjukkan bahwa $\mathrm{K}$ value ikan whiting yang disimpan dalam es berkorelasi positif secara linier dengan total DPS pada 10 hari pertama masa penyimpanan dan hasil penelitian Alasalvar et al. (2002) pada ikan seabream dengan korelasi positif antara $K$ value dan DPS $(r=0,99)$. Demikian juga menurut Liu et al. (2010), K value pada filet nila yang dikemas dalam kemasan plastik dan disimpan dalam boks berisi es, meningkat secara linier selama penyimpanan dan berkorelasi positif dengan penurunan penerimaan sensori $(r=94)$ dengan nilai awal $<20 \%$ dan $68 \%$ pada penyimpanan 13 hari (produk ditolak panelis). Pada penelitian ini, $K$ value rata-rata mencapai $68,02 \%$ setelah 12 hari penyimpanan, sementara DPS mencapai 19,4. Pada kondisi ini nila segar masih diterima panelis. Apabila dilihat dari nilainya, $K$ value filet nila pada penyimpanan 13 hari sebesar $68,02 \%$ Liu et al., 2010) hampir sama dengan $K$ value nila segar pada penelitian ini; namun demikian kondisi nila segar belum ditolak, sedangkan filet nila telah ditolak panelis. Penolakan terhadap filet nila pada penelitian Liu et al. (2010) didasarkan pada kondisi visual yang telah menurun yaitu timbulnya off flavor, terbentuknya lendir yang kental serta lunaknya tekstur filet yang kemungkinan karena aktivitas bakteri yang jumlahnya cukup tinggi dan mencapai $10^{7}$, sementara rata-rata total bakteri nila segar pada 12 hari penyimpanan pada penelitian ini masih relatif rendah, yakni $10^{5}$ dengan kondisi visual lendir tipis, bau agak amis, kondisi perut masih kuat, dan belum terjadi diskolorasi.

Korelasi positif antara kenaikan $K$ value dengan penurunan kesegaran juga terjadi pada ikan trout yang disimpan dalam es dan semakin tinggi $K$ value maka kesegaran ikan semakin rendah (Ozogul \& Ozogul, 2002). Pada ikan gilthead yang disimpan dalam es, $K$ value meningkat hampir linier selama penyimpanan dan berkorelasi positif dengan nilai flavor $(r=0,99) ; K$ value pada ikan gilthead dengan kondisi sangat segar berada di bawah $10 \%$ dan setelah penyimpanan

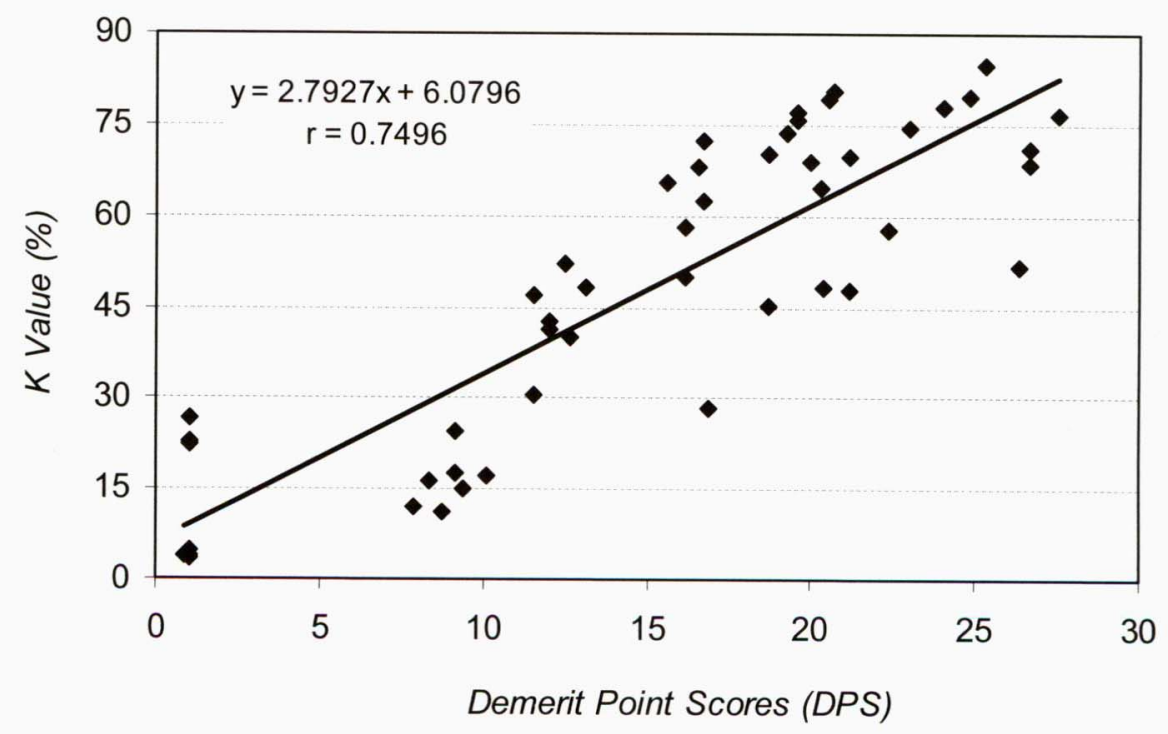

Gambar 6. Pola hubungan antara DPS dengan $K$ value pada ikan nila selama penyimpanan dalam es. Figure 6. Correlation between DPS and $K$ value of tilapia during storage in ice. 


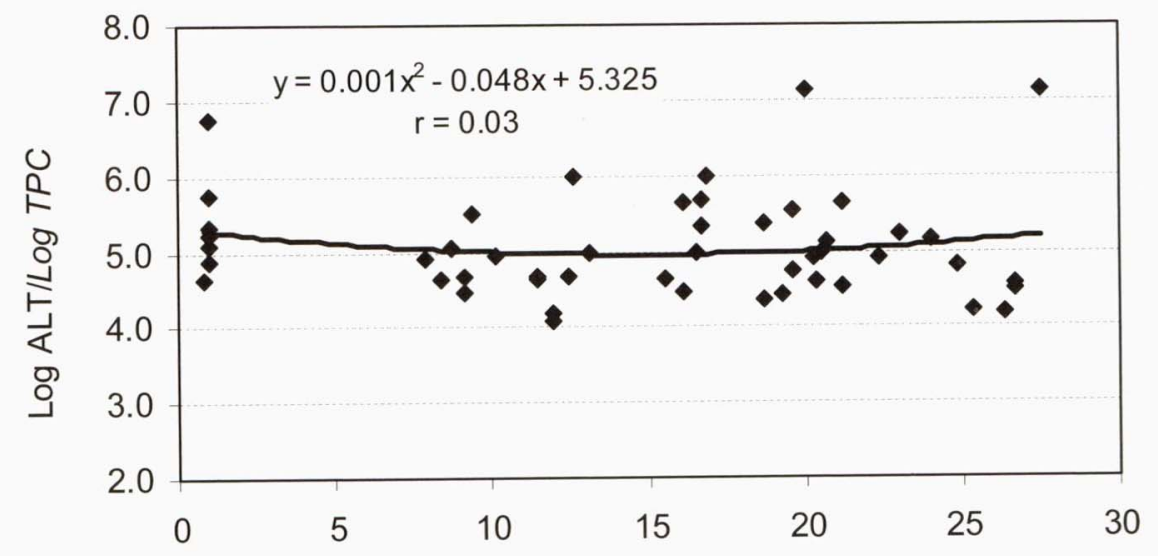

Demerit Point Scores (DPS)

Gambar 7. Pola hubungan antara DPS dengan log jumlah bakteri total pada ikan nila selama penyimpanan dalam es.

Figure 7. Correlation between DPS and log total bacteria of tilapia during storage in ice.

16 hari $K$ value mencapai 33-35\% (Lougovoisa et al., 2003). Namun demikian, beberapa ikan, misalnya ikan cod Atlantik, telah mencapai $K$ value maksimum jauh sebelum masa simpannya selesai (Huss, 1995).

Berbeda dengan pola hubungan antara parameter kimia (TVB dan $K$ value) dengan DPS, korelasi antara log jumlah bakteri total dengan DPS bukan positif (Gambar 7), karena log jumlah bakteri total cenderung konstan dengan bertambahnya waktu penyimpanan (Gambar 4) dan rata-rata jumlah bakteri masih dalam batas standar untuk produk ikan segar, yaitu $10^{5}$ (Huss, 1995), sementara DPS meningkat dengan bertambahnya waktu penyimpanan (Gambar 1). Terhambatnya pertumbuhan bakteri karena suhu dingin (penambahan es), dan terjadinya pencucian yang signifikan ketika air hasil pencairan es mencuci permukaan ikan selama penyimpanan merupakan salah satu kemungkinan penyebab mengapa jumlah bakteri total tidak berubah secara signifikan selama penyimpanan (Bremner et al., 1988). Pada umumnya, bertambahnya waktu penyimpanan, akan meningkatkan jumlah bakteri total pada ikan, sebagaimana hasil penelitian Özyurt et al. (2009) pada penyimpanan ikan goldband goatfish dan red mullet; Adoga et al. (2010) pada penyimpanan ikan nila; Okeyo et al. (2009) pada penyimpanan ikan nile perch dan hasil penelitian Liu et al. (2010) pada penyimpanan filet nila. Namun demikian, hal tersebut tidak selalu terjadi, sebagaimana diungkapkan oleh David et al. (2006) bahwa nilai jumlah bakteri total dan bakteri pembentuk $\mathrm{H}_{2} \mathrm{~S}$ masih rendah sampai dengan 9 hari penyimpanan yang kemungkinannya disebabkan oleh jumlah bakteri total pada awal percobaan yang sangat rendah karena cara pengesan yang sangat baik sehingga kenaikan jumlah bakteri total selama penyimpanan tidak signifikan. Dinyatakan pula bahwa pengukuran secara mikrobiologi menggunakan parameter jumlah bakteri total untuk mengamati penurunan mutu kesegaran ikan karena aktivitas bakteri kadang kurang sesuai karena kecilnya proporsi bakteri penentu kebusukan dari total mikroflora pada hasil hitungan jumlah bakteri total (Anon., 2009).

\section{KESIMPULAN}

Dari hasil percobaan pengamatan terhadap penurunan kesegaran ikan nila selama pengesan dan hubungan antar parameter mutu, dapat disimpulkan sebagai berikut:

1. Korelasi antara parameter sensori DPS dengan parameter mutu kimia adalah positif dengan $r=$ 0,91 untuk TVB dan 0,75 untuk $K$ value, tetapi tidak terjadi korelasi positif dengan parameter mutu mikrobiologi/jumlah bakteri total $(r=0,003)$.

2. Hasil analisis sensori dengan metode DPS menunjukkan bahwa ikan nila segar masih dapat diterima sampai 15 hari penyimpanan dalam es dan sudah tidak layak untuk dikonsumsi setelah 18 hari penyimpanan dengan DPS 25,9.

3. Hasil analisis mutu kimiawi menunjukkan bahwa pada 18 hari penyimpanan nilai TVB mencapai 48 $\mathrm{mgN} \%$ dan terdapat korelasi positif antara kenaikan TVB dengan peningkatan waktu penyimpanan dengan nilai $r=0,94$, sedangkan $K$ value pada 18 hari penyimpanan mencapai $76,4 \%$ dan terdapat korelasi positif antara kenaikan $K$ value dengan peningkatan waktu penyimpanan dengan nilai $r=0,75$ 
4. Hasil analisis mutu mikrobiologi menunjukkan bahwa pada penyimpanan 18 hari nilai jumlah bakteri total berada pada batas penerimaan $\left(10^{5}\right.$ cfu) dan tidak terjadi korelasi positif antara log bakteri total dengan peningkatan waktu penyimpanan dengan nilai $r=0,006$

\section{DAFTAR PUSTAKA}

Adoga, I.J., Joseph, E., and Samuel, O.F. 2010. Storage life of tilapia (Oreochromis niloticus) in ice and ambient temperature. Researcher. 2(5): 39-44.

Ahimbisibwe, J.B., Inoue, K., Shibata, T., and Aoki, T. 2010. Effect of bleeding on the quality of amberjack Seriola dumerili., and red sea bream Pagrus major muscle tissues during iced storage. Fish Sci. 76: 389-394.

Alasalvar, C., Taylor, K.D.A., and Shahidi, F. 2002. Comparative quality scoring of cultured and wild sea bream (Sparus aurata) stored in ice. J. Agric. Fd. Chem. 50: 2039-2045.

Anonymous. 2009. Freshness, quality and safety in seafoods. http://seafood.ucedavis.edu. Diakses pada bulan Maret 2010.

Ariyani, F. dan Dwiyitno. 2010. Kajian sensori dengan metode Demerit Point Score terhadap penurunan kesegaran ikan nila selama pengesan. Jurnal Pascapanen dan Bioteknologi Kelautan dan Perikanan. 5(2): 141-152.

Branch, A.C. and Vail, A.M.A. 1985. Bringing fish inspection into the computer age. Food Technol. Aust. 37(8): 352-355.

Bremner, H.A., Statham, J.A., and Sykes, S.J. 1985. Tropical species from North-West shelf of Australia: Sensory scoring and acceptability of fish stored on ice. In Reilly, A. (ed.) Spoilage of Tropical Fish and Product Development. Proceeding of a Symposium held in conjunction with the Sixth Session of the Indopacific Fishery Commision Working Party on Fish Technology and Marketing. RMIT, Melbourne, Australia, 23-26 October 1984. FAO, Rome. p. 41-53

Bremner, H.A., Olley, J., Statham, J.A., and Vail, A.M.A. 1988. Nucleotide catabolism: Influence on the storage life of tropical species of fish from the North west shelf of Australia. J. Food Sci. 53(1): 6-11.

BSN. 2006. SNI 01-2332.2006. Cara Uji Mikrobiologi. Bag. 3. Penentuan Angka Lempeng Total pada Produk Perikanan. Dewan Standardisasi Nasional, Jakarta.

David, G.J., Magnusson, H., and Palmadottir, H. 2006. Shelf life of herring (Clupea harengus) kept at different temperatures. Fisheries Training Programme. Reykjavik, Iceland. The United Nations University. 32 pp.

Hardy, R. and Smith, J.G.M. 1976. The storage of mackerel (Scomber scrombus). Development of histamine and rancidity. J. Sci. Food. 27: 595-599.

Huss, H.H. 1995. Quality and Quality Changes in Fresh Fish. FAO Fisheries Technical Paper. 348. FAO of the United Nations, Rome. 195 pp.
Howgate, P. 2010. A critical review of total volatile bases and trimethylamine as indices of freshness of fish. Part 2. Formation of the bases, and application in quality assurance. Electronic Journal of Environmental Agricultural and Food Chemistry. 9 (1): 58-88

Liu, S., Fan, W., Zhong, S., Ma, C., Li, P., Zhou, K., Peng, Z., and Zhu, M. 2010. Quality evaluation of tray-packed tilapia fillets stored at $0^{\circ} \mathrm{C}$ based on sensory, microbiological, biochemical and physical attributes. African Journal of Biotechnology. 9(5): 692-701.

Lougovoisa, V.P., Kyranasb, E.R., and Kyranaa, V.R. 2003. Comparison of selected methods of assessing freshness quality and remaining storage life of iced gilthead sea bream (Sparus aurata). Food Research International. 36: 551-560.

Luten, J.B., Vermaat, R., Bouquet, W., and van Barneveld, E. 1997. ATP-breakdown products, measured by ionpair HPLC, in whiting (Merlangius merlangus) during controlled ice-storage quality profile experiments. In Luten, J.B., Borresen, T., and Oehlenschlager, J. (eds.). Seafood from Producer to Consumer, Integrated Approach to Quality. Amsterdam. Elsevier Sci. B.V. p. 561-569.

Martinsdóttir, E., Odoli, C.O., Lauzon, H.L., Sveinsdottir, K., Magnusson, H., Arason, S., and Johannsson, R. 2009. Optimal storage conditions for fresh farmed tilapia (Oreochromis niloticus) fillets. Matis Food Research, Innovation and Safety. Reykjavik-Iceland. Skýrsla Matís. $81 \mathrm{pp}$.

Massa, A.E., Palacios. D.L., Palacios, M.E., Paredi, and Crupkin, M. 1998. Chemical, Microbiological, and Sensory scoring of Freshness in Ice Stored Flounder (Paralichthys patagonicus). 2nd Mercosur Congress on Chemical Engineering. 4th Mercosur Congress on Process Systems Engineering. 7 pp.

Miwa, K. and Ji, L.S. 1992. Laboratory Manual on Analytical Methods and Procedures for Fish and Fish Products. 2nd. Singapore: Marine Fish. Res, Dep., SEAFDEC

Niven, C.F., Jr., Jeffrey, M.B., and Corlett, D.A.Jr. 1981. Differential plating medium for quantitative detection of histamine-producing bacteria. Appl. Environ. Microbiol. 41(1): 321-322.

Odoli, C.O. 2009. Optimal Storage Conditions for Fresh Farmed Tilapia (Oreochromis niloticus) Fillets. Thesis. Department of Food Science and Nutrition. University of Iceland. $96 \mathrm{pp}$.

Oehlenschlager, J. 1997. Volatile amines as freshness/ spoilage indicators. A Literature review. In Luten, J.B., Borresen, T., and Oehlenschlager, J. (eds.). Seafood from Producer to Consumer, Integrated Approach to Quality. Amsterdam. Elsevier Sci. B.V. p. 571-586.

Okeyo, G.O., Lokuruka, M.N.I., and Matofari J.W. 2009. Nutritional composition and shelflife of the lakevictoria nile perch (Lates niloticus) stored in ice. African Journal of Food Agriculture Nutrition and Development.

Özyurt, G., Kuley, E., Özkütük, S., and Özogul, F. 2009. Sensory, microbiological and chemical scoring of the freshness of red mullet (Mullus barbatus) and 
goldband goatfish (Upeneus moluccensis) during storage in ice. Food Chemistry. 114: 505-5

Ozogul, F. and Ozogul, Y. 2000. Comparison of methods used for determination of total volatile basic nitrogen (TVB-N) in rainbow trout (Oncorhynchus mykiss). Turk J. Zool. 24: 113-120.

Özogul, Y., Boga, E.K., Tokur, B., and Özogul, F. 2011. Changes in biochemical, sensory and microbiological quality indices of common sole (Solea solea) from the mediterranean sea, during ice storage. Turk. J. Fish. Aquat. Sci.11: 243-251.

Rahman, H.A. and Olley, J. 1984. Scoring of sensory techniques for quality scoring of australian fish. CSRIO. Tasmanian Regional Laboratory. Occasional. (8): 84.

Rodríguez-Jérez, J.J., Hernández-Herrero, M.M., and Roig-Sagués, A.X. 2011. New methods to determine fish freshness in research and industry. http:// www.pdf.kq5.org/New-methods-to-determine-fishfreshness-in-research-and-industry. 63-68. Diakses pada bulan Mei 2011
Sikorski, Z.E., Kolakowska, A., and Burt, J.R. 1990. Postharvest biochemical and microbial changes. In Sikorski, Z.E. (ed.) Seafood: Resources, Nutritional Composition and Preservation. CRC Press Inc., Boca Raton, FL. p. 55-75.

Soccol, M.C.H., Oetterer, M., Gallo, C.R., Spoto, M.H.F., and Biat, D.O. 2005. Effects of modified atmosphere and vacuum on the shelf life of Tilapia (Oreochromis niloticus) fillets. Braz. J. Food Technol. 8(1): 7-15.

Uchiyama, H., Ehira, S., and Kato, N. 1972. Analytical methods for estimating freshness of fish. In: Utilization of Marine Products. OTCA, Japan. p. 206214.

Urbieta and Ginés, R. 2011. Optimisation of slaughtering method in gilthead sea bream (Sparus aurata). Industrial application in fish farms. http:// ressources.ciheam.org/om/pdf/c51/00600293.pdf. Diakses pada bulan April 2011.

Wijayanti, I., Swastawati, F., dan Agustini, T.W. 2006. Pola perubahan k-value dan ORP ikan cakalang (Katsuwonus pelamis) pada penyimpanan suhu rendah $\left(+11^{\circ} \mathrm{C}\right)$. Jurnal Pasir Laut. 2(1): 1-12. 


\section{LAMPIRAN/APPENDIX 1. Lembar penilaian DPS/Score Sheets of DPS}

Jenis produk $/$ Type of Products $=$ Nila segar $/$ Fresh tilapia

\begin{tabular}{|c|c|c|c|c|}
\hline $\begin{array}{c}\text { Parameter Kualitasl } \\
\text { Quality Parameters } \\
\end{array}$ & \begin{tabular}{c|} 
Karakterl \\
Characteristics
\end{tabular} & \begin{tabular}{|l|} 
Nilai/ \\
Score \\
\end{tabular} & Deskripsi/Description & $\begin{array}{c}\text { Kodel } \\
\text { Code }\end{array}$ \\
\hline \multirow{16}{*}{$\begin{array}{l}\text { Kenampakan Umum/ } \\
\text { General Appearance }\end{array}$} & \multirow{4}{*}{$\begin{array}{l}\text { Kenampakan/ } \\
\text { Appearance }\end{array}$} & 0 & Sangat cerah/Very bright & \\
\hline & & 1 & Cerah/Bright & \\
\hline & & 2 & Agak kusam/Slightly dull & \\
\hline & & 3 & Kusam/Dull & \\
\hline & \multirow[t]{2}{*}{ Kulit/Skin } & 0 & Kencang/Firm & \\
\hline & & 1 & Lunak/Soft & \\
\hline & \multirow[t]{3}{*}{ Sisik/Scale } & 0 & Kuat, erat/Firm & \\
\hline & & 1 & Agak mudah lepas/Slightly loose & \\
\hline & & 2 & Mudah Lepas/Loose & \\
\hline & \multirow[t]{4}{*}{ Lendir/Slime } & 0 & Tidak ada/Absent & \\
\hline & & 1 & Tipis/Slightly slimy & \\
\hline & & 2 & Tebal/Slimy & \\
\hline & & 3 & Sangat tebal/Very slimy & \\
\hline & \multirow{3}{*}{$\begin{array}{l}\text { Kekakuan/ } \\
\text { Stiffness }\end{array}$} & 0 & Sebelum rigor/Pre-rigor & \\
\hline & & 1 & Rigor/Rigor & \\
\hline & & 2 & Sesudah rigor/Post-rigor & \\
\hline \multirow[t]{11}{*}{ Mata/Eyes } & \multirow{3}{*}{$\begin{array}{l}\text { Kebeningan/ } \\
\text { Clarity }\end{array}$} & 0 & Bening/Clear & \\
\hline & & 1 & Agak berkabut/Slightly cloudy & \\
\hline & & 2 & Berkabut/Cloudy & \\
\hline & \multirow[t]{3}{*}{ Bentuk/Shape } & 0 & Normal/Normal & \\
\hline & & 1 & Agak cekung/Slightly sunken & \\
\hline & & 2 & Cekung/Sunken & \\
\hline & \multirow[t]{2}{*}{ Pupil/Irish } & 0 & Kelihatan/Visib/e & \\
\hline & & 1 & Tidak kelihatan/Not visib/e & \\
\hline & \multirow[t]{3}{*}{ Darah/Blood } & 0 & Tidak berdarah/No blood & \\
\hline & & 1 & Agak berdarah/Slightly bloody & \\
\hline & & 2 & Sangat berdarah/Very bloody & \\
\hline \multirow[t]{10}{*}{ Insang/Gills } & \multirow[t]{3}{*}{ Warna/Colour } & 0 & Merah, spesifik/Characteristics red & \\
\hline & & 1 & Agak gelap, agak pudar/Slightly dark, Slightly faded & \\
\hline & & 2 & Sangat gelap, sangat pudar/very dark, very faded & \\
\hline & \multirow[t]{3}{*}{ Lendir/Mucous } & 0 & Tidak ada/Absent & \\
\hline & & 1 & Tipis/Moderate & \\
\hline & & 2 & Tebal/Excessive & \\
\hline & \multirow[t]{4}{*}{ Bau/Smell } & 0 & $\begin{array}{l}\text { Segar berminyak, rumput laut, logam/Fresh oily, } \\
\text { metallic, seaweed }\end{array}$ & \\
\hline & & 1 & Amis/Fishy & \\
\hline & & 2 & Basi/Stale & \\
\hline & & 3 & Busuk/Spoilt & \\
\hline \multirow[t]{7}{*}{ Perut/Belly } & \multirow{4}{*}{$\begin{array}{l}\text { Diskolorasi/ } \\
\text { Discoloration }\end{array}$} & 0 & Tidak ada/Absent & \\
\hline & & 1 & Terdeteksi/Detectable & \\
\hline & & 2 & Sedan/Moderate & \\
\hline & & 3 & Banyak/Excessive & \\
\hline & \multirow{3}{*}{$\begin{array}{l}\text { Kekakuan/ } \\
\text { Firmness }\end{array}$} & 0 & Kencang/Firm & \\
\hline & & 1 & Lunak/Soft & \\
\hline & & 2 & Pecah/Burst & \\
\hline
\end{tabular}


F. Ariyani, J.T. Murtini, dan F. Andayani

Jenis produk $/$ Type of Products $=$ Nila segar $/$ Fresh tilapia

\begin{tabular}{|c|c|c|c|c|}
\hline $\begin{array}{l}\text { Parameter Kualitas/ } \\
\text { Quality Parameters }\end{array}$ & $\begin{array}{c}\text { Karakterl } \\
\text { Characteristics }\end{array}$ & $\begin{array}{l}\text { Nilai/ } \\
\text { Score }\end{array}$ & Deskripsi/Description & $\begin{array}{l}\text { Kodel } \\
\text { Code }\end{array}$ \\
\hline \multirow[t]{7}{*}{ Anus/Vent } & \multirow{3}{*}{$\begin{array}{l}\text { Kondisi/ } \\
\text { Condition }\end{array}$} & 0 & Normal/Normal & \\
\hline & & 1 & Agak pecah, berair/Slightly break, exudes & \\
\hline & & 2 & Pecah, berair, terbuka/Excessive, opening & \\
\hline & \multirow[t]{4}{*}{ Bau/Smell } & 0 & Segar/Fresh & \\
\hline & & 1 & Netral/Neutral & \\
\hline & & 2 & Amis/Fishy & \\
\hline & & 3 & Busuk/Spoilt & \\
\hline \multirow{6}{*}{$\begin{array}{l}\text { Rongga perut/ } \\
\text { Belly cavity }\end{array}$} & \multirow[t]{3}{*}{ Stains } & 0 & Bercahaya, warna spesifik/Opalescent & \\
\hline & & 1 & Keabu-abuan/Greyish & \\
\hline & & 2 & Kuning kecoklatan/Yellow-brown & \\
\hline & \multirow[t]{3}{*}{ Darah/Bloods } & 0 & Merah/Red & \\
\hline & & 1 & Merah gelap/Dark red & \\
\hline & & 2 & Coklat/Brown & \\
\hline
\end{tabular}

Nilai minimal/Minimum score : 0

Nilai maksimal/Maximum score : 39 